\title{
First record of Burmeister's porpoise (Phocoena spinipinnis) in the Falkland Islands (Malvinas)
}

\author{
Caroline R. Weir ${ }^{1 *}$ (D) and Susan Rutherford ${ }^{2}$
}

\begin{abstract}
The Burmeister's porpoise Phocoena spinipinnis is a small, poorly-studied, and Near Threatened cetacean species, with a limited geographic range comprising the Pacific and Atlantic coastal temperate waters of five South American countries. Here we describe a stranding of a freshly-dead adult male Burmeister's porpoise that was discovered opportunistically on the eastern coast of the Falkland Islands $\left(51^{\circ} 40.9^{\prime} \mathrm{S}, 57^{\circ} 43.2 \mathrm{~W}\right.$ ) on 29 June 2019 . Unfortunately the carcass was removed by an unknown source prior to any scientific sampling, but the morphological features revealed in photographs taken of the dead animal were sufficient to verify the species identification. This is the first known record of Burmeister's porpoise in the Falklands, confirming a sixth range state for the species and expanding its known distribution range eastwards from the previous nearest documented occurrence in Tierra del Fuego by at least $600 \mathrm{~km}$ across the Patagonian Shelf.
\end{abstract}

Keywords: Distribution, Phocoena spinipinnis, Range state, Falklands, South-West Atlantic, Stranding

\section{Background}

The Burmeister's porpoise (Phocoena spinipinnis) has a distribution that is endemic to the Pacific and Atlantic coastal temperate waters of southern and central South America (Brownell Jr. and Clapham 1999). It occurs along the coasts of both ocean basins from Tierra del Fuego northwards to Peru $\left(\sim 5^{\circ} \mathrm{S}\right)$ in the Pacific and to southern Brazil $\left(\sim 29^{\circ} \mathrm{S}\right)$ in the Atlantic, although it remains unclear whether or not that distribution is continuous (Corcuera et al. 1995; Goodall et al. 1995a, 1995b). The species is currently classified globally as Near Threatened (Félix et al. 2018), based on its limited range, low densities, and high mortality in some fisheries (both incidental bycatch and directed takes).

Burmeister's porpoises are poorly-studied throughout their range (Brownell Jr. and Praderi 1982), due not least to inherent difficulties with observing and identifying the species at sea because of the small body size, low dorsal profile (resulting from the characteristic fin shape and placement), small group size, and inconspicuous behaviour (Goodall et al. 1995a; Rosa et al. 2005). Consequently,

\footnotetext{
* Correspondence: swpo@conservation.org.fk

${ }^{1}$ Falklands Conservation, Jubilee Villas, Stanley FIQQ 1ZZ, Falkland Islands Full list of author information is available at the end of the article
}

much of the available information on their conservation status, abundance, distribution, ecology and life-history originates from strandings and from animals captured in fisheries (e.g. Corcuera et al. 1995; Goodall et al. 1995a). They have primarily been reported from nearshore, shallow habitats, including bays, estuaries, channels and fjords (Brownell Jr. and Praderi 1982; Corcuera et al. 1994; Goodall et al. 1995a, 1995b; Brownell Jr. and Clapham 1999), and acoustic data suggest that they preferentially forage in water depths shallower than $50 \mathrm{~m}$ and within $30 \mathrm{~km}$ of the coast (Clay et al. 2018).

Here, we report the first known record of a Burmeister's porpoise in the Falkland Islands, documenting a new range state for the species and extending its known global distribution range.

\section{Methods and results}

At dusk on 29 June 2019, a dead small cetacean was opportunistically discovered by a family visiting the north coast of the Cape Pembroke peninsula $\left(51^{\circ} 40.9^{\prime} \mathrm{S}\right.$, $57^{\circ} 43.2^{\prime} \mathrm{W}$, Fig. 1) near Stanley, in the Falkland Islands. The Falklands are located on the Patagonian continental shelf $(<200 \mathrm{~m}$ depth), which extends easterly into the Atlantic from South America. 


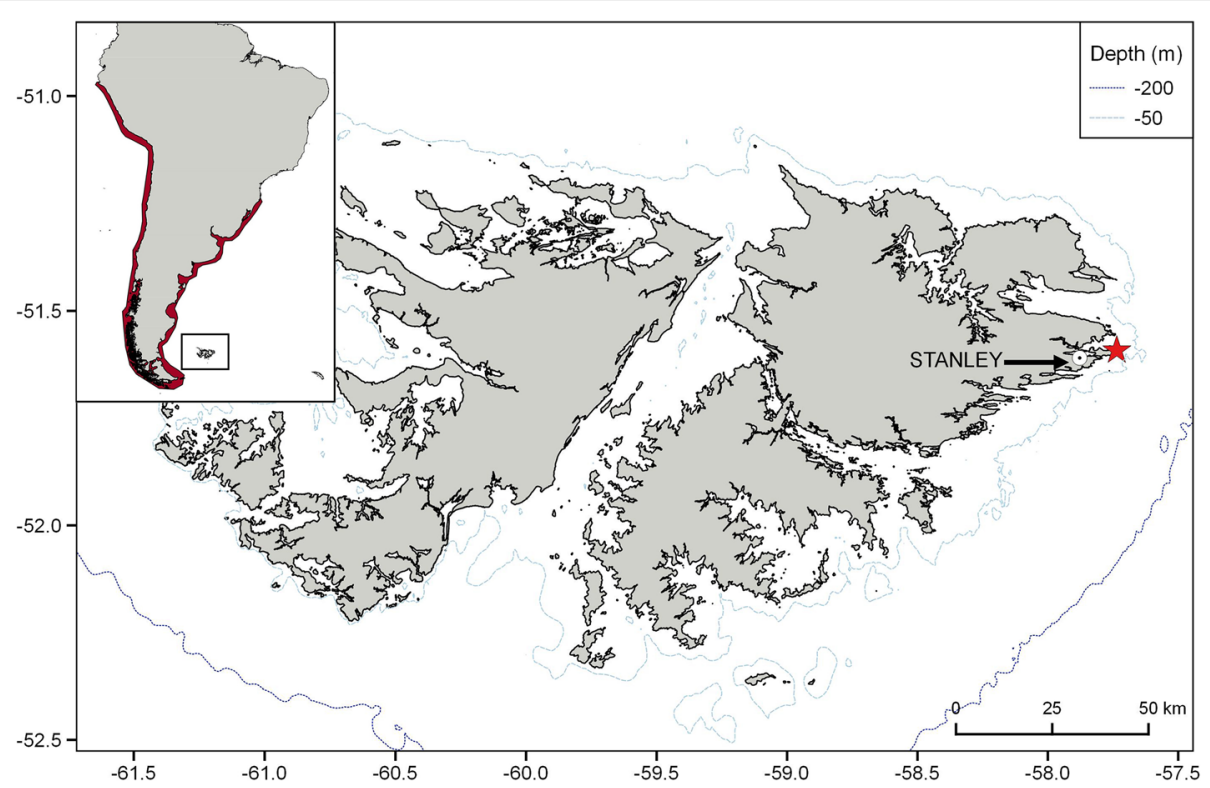

Fig. 1 Location of the Burmeister's porpoise stranding (red star) in the Falkland Islands. Inset shows the previously-documented distribution range along the coasts of South America (Félix et al. 2018)

The animal was initially found lying on rocks at the high tide line, and the family relocated the carcass to the adjacent grassy cliff to prevent it from being washed away in the tide. Later that evening, staff from Falklands Conservation (FC) received notification of the event (which was variously reported as a "whale", a "pilot whale" and a "dolphin"), but were unable to locate the animal during a site visit shortly after dawn the following morning (30 June). The site was visited again by the Falkland Islands Government (FIG) Environmental Officer on the 1 July, again with no sign of the carcass. Consequently, it was concluded that the dead animal had been removed by an unknown source, and no specimen samples could be collected.

Photographs taken by several people on the evening of 29 June were subsequently provided to FC for species identification. Light scavenging had occurred on the left side and dorsal surface of the animal, but the right side was fresh and unscavenged (Fig. 2). The specimen was identified as a Burmeister's porpoise based on the following features (Fig. 2; Brownell Jr. and Praderi 1982; Brownell Jr. and Clapham 1999): (1) the dorsal fin shape, which comprised a sloped leading edge and a straight trailing edge with a pointed tip; (2) location of the dorsal fin posterior to the midpoint of the back; (3) a largely uniform dark grey body colouration with lighter grey areas on the chin and abdominal field and a pale patch around the anus; (4) a dark eye patch; (5) a conical head without a well-defined beak; (6) proportionately large and broad flippers; and (7) the presence of spatulate teeth typical of phocoenids. It was not possible to clearly see the tubercles on the leading margin of the dorsal fin in the photographs, due to the damaged skin in that area. Although the view of the ventral region within the images was angled, the animal was identified as male based on clear separation between the genital slit and anus (Fig. 2).

No obvious indications of cause of death were apparent from the available photographs. The specimen was considered to be freshly-dead, since subtle details of the pigmentation pattern including a pale halo around the eye patch and a thin light stripe extending from the flipper towards the chin were still visible but are known to disappear quickly after death (Goodall et al. 1995b).

The removal of the carcass prevented accurate morphometric data from being collected. Length estimates (fluke notch to tip of snout) derived from available markers in the photographs were in the region of 165 to $187 \mathrm{~cm}$; however, both the animal's body and the markers were angled in all photographs and those length estimates are therefore only indicative. The mean body lengths of a sample of mature males and females from Peru, Chile and Argentina were 162.7 and $167.3 \mathrm{~cm}$ respectively (Goodall et al. 1995b), although animals in the temperate Atlantic apparently reach slightly larger body size (Corcuera et al. 1995). Sexual maturity is attained at average lengths of 159.9 and $154.8 \mathrm{~cm}$ for males and females respectively (Brownell Jr. and Clapham 1999). Consequently, the estimates from the photographs were consistent with the Falklands specimen having likely comprising a mature adult. 

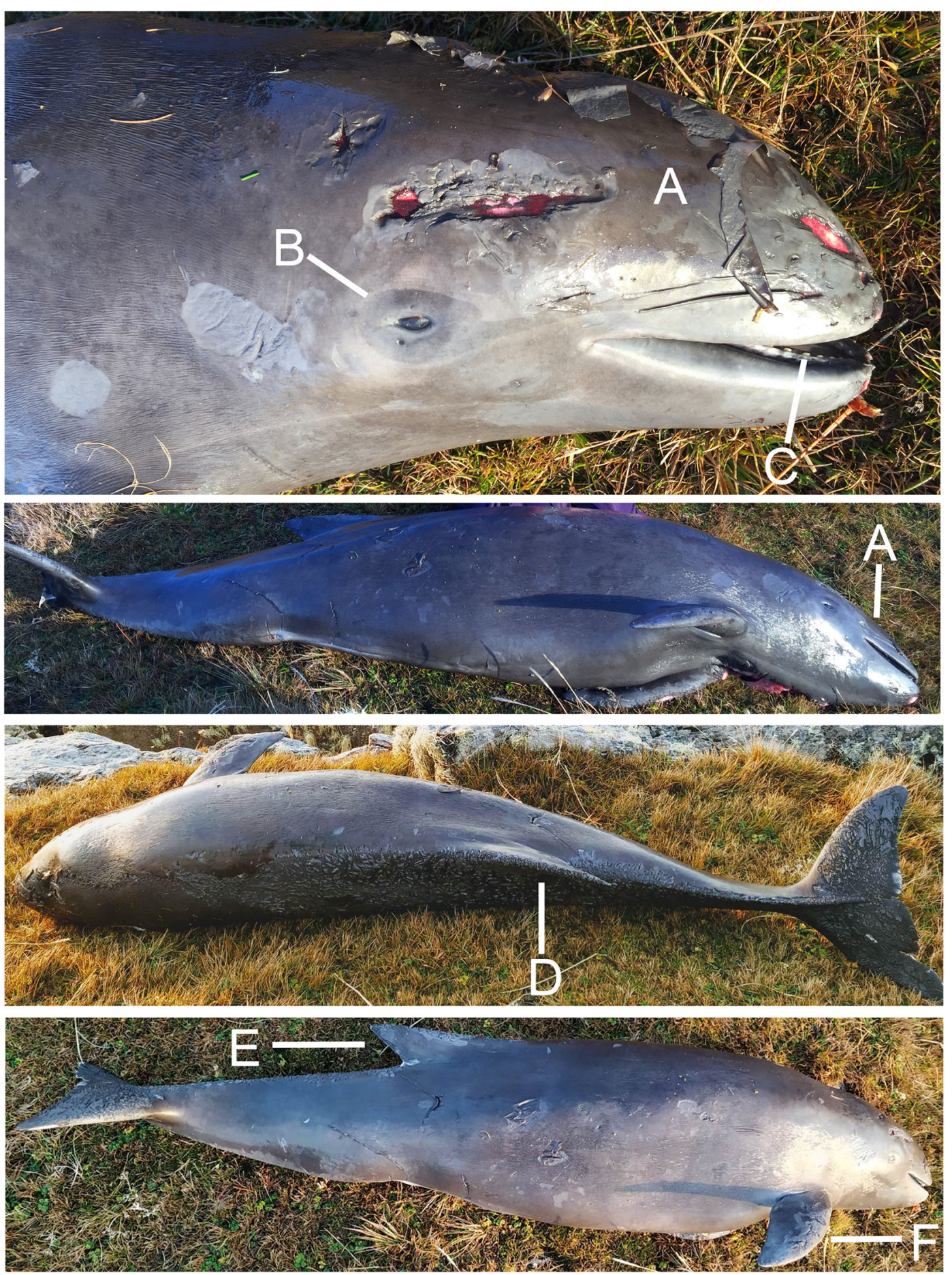

Fig. 2 Stranded Burmeister's porpoise in the Falkland Islands. Key diagnostic morphological features indicated are: a conical head without a welldefined beak, $\mathbf{b}$ dark eye patch, $\mathbf{c}$ spatulate teeth, $\mathbf{d}$ dorsal fin located posterior to the midpoint of the back, e sloped leading edge and a straight trailing edge to dorsal fin, $\mathbf{f}$ broad flippers. Photographs courtesy of Susan Rutherford and Monika Łukomska

\section{Discussion}

The Burmeister's porpoise was previously known from five range states, comprising Peru, Chile, Argentina, Uruguay and Brazil (Brownell Jr. and Praderi 1982;
Félix et al. 2018). Here, we document its occurrence for the first time in the Falkland Islands, confirming a sixth range state. The nearest published records of Burmeister's porpoises to the Falklands originate from Tierra 
del Fuego, where bycatches have been reported along the north-east coast and the species is sighted occasionally in the Magellan Strait and the Beagle Channel (Goodall et al. 1995a, 1995b). Tierra del Fuego is located approximately $400 \mathrm{~km}$ from the westernmost coast of the Falkland Islands and $600 \mathrm{~km}$ from the stranding site. The Falklands stranding therefore extends the known global range significantly eastwards across the Patagonian Shelf.

Genetic and morphological evidence supports the existence of distinct populations of Burmeister's porpoises on the Pacific and Atlantic coasts of South America (Brownell Jr. and Praderi 1982; Corcuera et al. 1995; Rosa et al. 2005). Animals in Uruguay and Argentina have larger body sizes than those in Peru and Chile (Brownell Jr. and Praderi 1982; Corcuera et al. 1995). Corcuera et al. (1995) concluded that Uruguayan and Argentinean porpoises may represent a single temperate Atlantic stock extending southwards to at least $38-39^{\circ} \mathrm{S}$, but noted that the status of those porpoises occupying the colder waters further south in the Magellan Strait and Beagle Channel remained unclear. Had the Falklands carcass been available for sampling, the collection of tissue samples and morphological measurements from the specimen may have contributed to assessing the population structure of Burmeister's porpoises in the littleknown subantarctic portion of the species range in the south-west Atlantic.

No previous stranding records of Burmeister's porpoise exist in the FIG cetacean stranding database (which contains records originating back to the late 1800s). No sightings of the species in Falklands' waters have been reported, despite comprehensive year-round coverage over the entire Falklands shelf in the late 1990s (White et al. 2002) and the onset of systematic cetacean sighting surveys in coastal waters in recent years (e.g. Weir 2017). Consequently, the status of the species in the Islands remains unknown. The possibility that the animal died at sea and drifted passively to the Falklands on ocean currents cannot be eliminated, but is considered unlikely given the fresh condition of the carcass and the location of the stranding site on the far eastern side of the Islands and furthest away from the known species range along the South American continent. If the animal was alive at sea within the Falklands Exclusive Economic Zone (EEZ) prior to the stranding, explanatory possibilities include: (1) the occurrence was an atypical event outside of the species usual distribution range; (2) individuals occasionally enter the Falklands EEZ during longer-range movements from the South American mainland; or (3) Burmeister's porpoises routinely occur in Falklands' waters but have simply remained unrecorded to date. Recent acoustic deployments detected Burmeister's porpoises in neritic habitat up to $200 \mathrm{~m}$ depth and over $100 \mathrm{~km}$ offshore in Peru (Clay et al. 2018). The wide expanse of Patagonian Shelf located between the Falklands and mainland South America is shallow ( $<200 \mathrm{~m}$ depth) and potentially also provides suitable neritic habitat for the species. Long-range seasonal movements exceeding 2000 $\mathrm{km}$ have recently been revealed by satellite-tracking of harbour porpoises (Phocoena phocoena) in Greenland (Nielsen et al. 2018), indicating that movements of several hundred kilometres between South America and the Falklands may be well within the capacity of a phocoenid species. There are also likely to be available prey for Burmeister's porpoises over the Patagonian Shelf, since documented prey species such as squid (including Loligo spp.), crustaceans and Fuegian sardines (Sprattus fuegensis: Goodall et al. 1995b) occur around the Falklands.

While the status of the species cannot be ascertained from a single stranding event, the record does raise the possibility that Burmeister's porpoises may be a previouslyoverlooked component of the Falklands' cetacean community. The species is challenging to visually detect at sea (Goodall et al. 1995a; Brownell Jr. and Clapham 1999; Félix et al. 2018), and particularly in higher-latitude regions such as the Falklands where sea conditions are rarely calm. It is also noteworthy that a significant amount of information on the occurrence of Burmeister's porpoises in other countries has originated from incidental captures in fisheries (particularly gillnets) and deliberate takes for human consumption or crab bait (Goodall et al. 1995a, 1995b), rather than from sightings of live animals. In the Falklands there is a complete absence of inshore fishing, and no gillnet or crab fisheries, which further reduces the likelihood of Burmeister's porpoises being documented. Strandings provide a useful indication of the occurrence of some scarcer species or those occupying offshore habitats (e.g. beaked whales; Otley 2012). However, small cetaceans appear to be under-represented in the Falklands strandings dataset. For example, both Peale's dolphin (Lagenorhynchus australis) and Commerson's dolphin (Cephalorhynchus commersonii) are numerous in nearshore Falklands' waters, yet fewer than 10 records of each (some of which actually comprised captures rather than strandings) are documented in the stranding database (Otley 2012). This may be the consequence of several factors: (1) the highly-convoluted coastline of the Islands and thinly-distributed human population outside of Stanley which limits the discovery of dead cetaceans; (2) many strandings are reported during routine local flights by the FIG air service, and are biased towards larger animals and mass strandings of multiple animals which are easier to detect from the air; and (3) all cetacean carcasses are subject to heavy and rapid scavenging from birds. The latter is certainly a significant issue affecting the discovery of dead small cetaceans: one very fresh juvenile hourglass dolphin (Lagenorhynchus cruciger) that washed ashore during May 2019 had been 
completely scavenged by birds by the time the carcass was visited for sampling $64 \mathrm{~h}$ later, leaving just a cleaned skeleton and the tail flukes. Therefore, it may be expected that stranded small cetaceans such as Burmeister's porpoise would have a relatively high likelihood of remaining unnoticed in the Falklands.

\section{Conclusions}

This paper has described a new occurrence of Burmeister's porpoise in the Falkland Islands, thus expanding the documented global distribution range of this Near Threatened species. The importance of Falklands' waters for the species remains unknown, and awaits clarification via additional sightings, strandings or acoustic records. However, the record implies that Burmeister's porpoises may be distributed over a wider area of the Patagonian Shelf, and range further from the coast, than previously understood.

\section{Acknowledgements}

We are grateful to the entire Rutherford family for discovering the stranded animal, moving it above the high tide line to keep it safe, and reporting it. Our thanks to Monika Łukomska for providing additional photographs of the porpoise, and to Pamela Quilodrán Jelbes, Andrew Stanworth and Denise Blake for their efforts to locate the porpoise carcass for sampling. Thanks to two reviewers for feedback that improved the draft manuscript.

\section{Authors' contributions}

SR found, photographed and reported the animal described here. CW wrote the manuscript. Both authors read and approved the final manuscript.

\section{Funding}

The authors received no funding in specific relation to the production of this paper.

\section{Availability of data and materials}

All information available on the stranding is presented in this paper.

\section{Ethics approval and consent to participate}

Not applicable.

\section{Consent for publication}

Not applicable.

\section{Competing interests}

The authors declare that they have no competing interests.

\section{Author details}

${ }^{1}$ Falklands Conservation, Jubilee Villas, Stanley FIQQ 1ZZ, Falkland Islands.

${ }^{2}$ Stanley, Falkland Islands.

Received: 31 July 2019 Accepted: 25 September 2019

Published online: 17 October 2019

\section{References}

Brownell RL Jr, Clapham PJ. Burmeister's porpoise Phocoena spinipinnis Burmeister, 1865. In: Ridgway SH, Harrison R, editors. Handbook of marine mammals, volume 6: the second book of dolphins and the porpoises. London: Academic Press; 1999. p. 393-410.

Brownell RL Jr, Praderi R. Status of Burmeister's porpoise, Phocoena spinipinnis, in southern south American waters. FAO Fish Ser. 1982;5:91-6.

Clay TA, Mangel JC, Alfaro-Shigueto J, Hodgson DJ, Godley BJ. Distribution and habitat use of a cryptic small cetacean, the Burmeister's porpoise, monitored from a small-scale fishery platform. Front Mar Sci. 2018;5:220.

Corcuera J, Monzon F, Aguilar A, Borrell A, Raga JA. Life history data, organochlorine pollutants and parasites from eight Burmeister's porpoises,
Phocoena spinipinnis, caught in northern argentine waters. Rep int Whal Commn. 1995;16:365-72.

Corcuera J, Monzon F, Crespo EA, Aguilar A, Raga JA. Interactions between marine mammals and the coastal fisheries of Necochea and Claromecó (Buenos Aires Province, Argentina). Rep int Whal Commn. 1994;15:283-90.

Félix F, Alfaro J, Reyes J, Mangel J, Dellabianca N, Heinrich S, Crespo E. Phocoena spinipinnis. The IUCN Red List of Threatened Species 2018. https://doi.org/10. 2305/IUCN.UK.2018-2.RLTS.T17029A50370481.en. Accessed 08 Jul 2019.

Goodall RNP, Norris KS, Harris G, Oporto JA, Castello HP. Notes on the biology of the Burmeister's porpoise, Phocoena spinipinnis, off southern South America. Rep int Whal Commn. 1995b;16:317-47.

Goodall RNP, Würsig B, Würsig M, Harris G, Norris KS. Sightings of Burmeister's porpoise, Phocoena spinipinnis, off southern South America. Rep Int Whal Commn. 1995a;16:297-316.

Nielsen NH, Teilmann J, Sveegaard S, Hansen RG, Sinding M-HS, Dietz R, HeideJørgensen MP. Oceanic movements, site fidelity and deep diving in harbour porpoises from Greenland show limited similarities to animals from the North Sea. Mar Ecol Prog Ser. 2018;597:259-72.

Otley H. The composition of the cetacean community in the Falkland (Malvinas) islands, southwest South Atlantic Ocean. Revista de Biol Mar Oceanografía. 2012;47:537-51.

Rosa S, Milinkovitch MC, Van Waerebeek K, Berck J, Oporto JA, Alfaro-Shigueto J, Van Bressem MF, Goodall R, Cassens I. Population structure of nuclear and mitochondrial DNA variation among south American Burmeister's porpoises (Phocoena spinipinnis). Conserv Genet. 2005;6:431-43.

Weir CR. Developing a site-based conservation approach for sei whales Balaenoptera borealis at Berkeley sound, Falkland Islands. Falklands Conservation: Stanley; 2017.

White RW, Gillon KW, Black AD, Reid JB. The distribution of seabirds and marine mammals in Falkland Islands waters. Joint Nature Conservation Committee: Peterborough; 2002.

\section{Publisher's Note}

Springer Nature remains neutral with regard to jurisdictional claims in published maps and institutional affiliations.

\section{Ready to submit your research? Choose BMC and benefit from:}

- fast, convenient online submission

- thorough peer review by experienced researchers in your field

- rapid publication on acceptance

- support for research data, including large and complex data types

- gold Open Access which fosters wider collaboration and increased citations

- maximum visibility for your research: over $100 \mathrm{M}$ website views per year

At BMC, research is always in progress.

Learn more biomedcentral.com/submissions 